\title{
Brothers and sisters, can you hear us? Remarks on facilitating a productive dialogue between the Western and African notions of practical theology in light of the decolonisation discourse
}

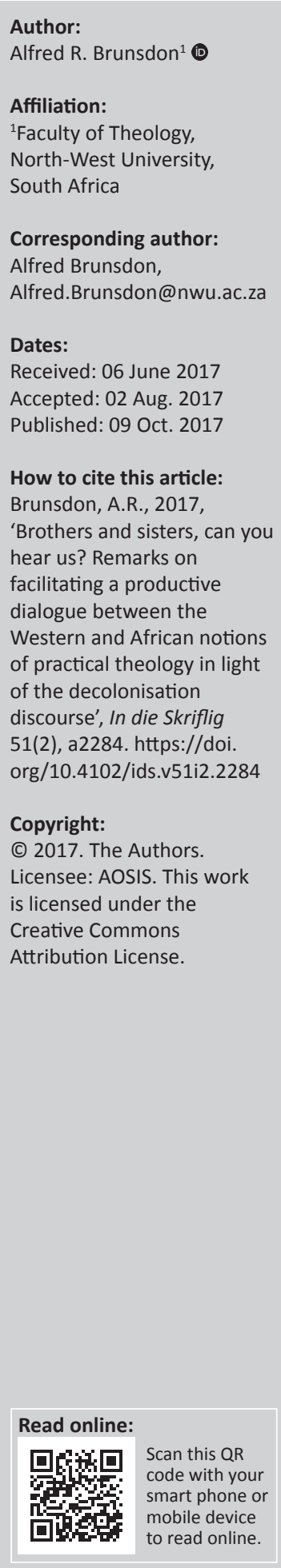

This article is conducted within the framework of the inter-contextual dialogue between the Western and African notions of practical theology. It sets out to probe the usefulness of the notion of decolonisation in the design of practical theology. The application of this notion in Emmanuel Lartey's Postcolonializing God - An African practical theology (2013) is investigated. An overview of Lartey's work is provided with the following question as subtext: Does the resultant African practical theology remain within 'hearing distance' from Western notions of practical theology that is traditionally reliant on a Christian epistemology? The finding is that decolonisation is of restricted use in the design of such a practical theology. While it provides insight into an authentic African practical theology, a critical discussion raises concerns regarding inclusivity, the perceived African context, the interrelatedness between culture and faith as well as the theological nature of the proposed African practical theology. The concluding section of the article suggests that inter-contextual dialogue can move forward on the basis of seeking the theological middle ground. In this regard the notion of Esther Acolatse's pastoral hermeneutic of primal speech is introduced that provides valuable parameters for inter-contextual dialogue. In creating room for intercultural dialogue, it operates from the stance of a perichoretic relationship between theology and culture. The resulting theologies thus retain their trinitarian character. Such an approach promises to keep dialogue partners from different contexts within hearing distance from one another, opening the possibility for symbiotic co-existence.

\section{Prologue}

Contributing to a festschrift presents the rare opportunity to introduce a research article on a more personal level. In this instance I would like to introduce and put the following research in an academic framework, by means of a few personal remarks about Professor Sarel van der Merwe.

Those of us who have been privileged to work closely with him as colleague were often afforded the opportunity to sit down for a conversation in his small office, tucked away in the corner of the base building of the Mafikeng Campus of the North-West University. These conversations mostly steered in the direction of the students we taught and in whose lives Professor van der Merwe invested most of his time and many of his personal resources. One of his great concerns was the fact that the predominantly African student population could only enrol for theological qualifications that were set in a Western paradigm. Consequently, he often voiced his desire for a truly integrated curriculum where Western and African notions of theology would meet to the benefit of the students and the current South African context.

Although Van der Merwe reached retirement age before this desire could be fulfilled, he certainly succeeded in sensitising his colleagues to the need to contextualise their particular disciplines within the African context. Therefore, this article fits within the framework of the inter-contextual dialogue between the Western and African notions of practical theology. It was also written in the hope that it would pay a fitting tribute to an academic and friend who embodied the missio Dei towards everyone he met during his long and blessed career.

\section{Introduction and research question}

In the South African context, the symbiotic relationship between the Western and African notions of practical theology has been an on-going quest for a few decades. This was mainly stimulated by the gradual realisation that a Western understanding of practical theology historically and 
academically steered and directed applications like pastoral care and counselling. Therefore, the absence of an African understanding and contribution to the field was accentuated by a growing number of voices (cf. Dames 2014:122; Louw 2008:147).

Bringing Western and African understandings of practical theology into a harmonious relationship is unfortunately neither simple, nor without challenges. As Berinyuu (1988:91) points out: transcultural engagement is 'not simply a matter of applying principles of pastoral care taken from another situation, or just applying some Biblical or Christian doctrines to the African situation'. This is partly due to the immense differences between the deep-rooted beliefs and value systems represented at the different ends of the cultural spectrum or, to put it in a metaphorical framework, Western and African practical theologians do not drink from the same epistemological wells to fuel practical theological praxis like pastoral care, homiletics and liturgy. In typical Western definitions of practical theology, the very theological nature of the discipline is accentuated in that practical theology critically reflects on faith practices in light of the Word of God (cf. Heyns \& Pieterse 1990:7; Swinton \& Mowat 2006:25). In African notions of practical theology the impression is often created that critical reflection takes place in light of culture and the beliefs undergirding a particular culture (cf. Masango 2013:746). Subsequently, entering this discourse often leaves participants with the feeling of 'not being heard' by the brothers and sisters 'from the other side', underlining the need for an on-going dialogue that can take the quest for a symbiotic relationship forward.

Adding a sense of urgency to the necessity for such dialogue was the recent widespread unrest on university campuses throughout the country. Generally referred to as the decolonisation of higher education, these protests were allegedly aimed against the 'epistemic violence' of the current higher education system (Heleta 2016). At the core of the movement for the decolonisation of higher education lies the desire to rid higher education of 'the domination of Western epistemological traditions' (Molefe 2016:32). In its place a form of higher education is sought that is 'free from Western epistemological domination, Eurocentrism, epistemic violence and world views that were designed to degrade, exploit and subjugate people in Africa' (Heleta 2016).

During this period of a growing realisation of the necessity for inter-contextual dialogue, the practical theological fraternity took note of the publication of Emmanuel Lartey's Postcolonializing God: An African Practical Theology (2013). This contribution of Lartey was of particular interest to this research for a number of reasons. First and foremost, it promised insight into an authentic African practical theology. As such, it represents a rare work, because few practical theologians have committed themselves to an explication of the concept of an African practical theology as opposed to a Western one. Equally important, it latches onto the notion of what was locally already known as decolonisation. In fact, the title suggests that Lartey is presenting an African practical theology that emanates from postcolonial criticism. As local expressions of decolonisation are committed to the eradication of all Western influence of theory, as stated above, decolonisation, at first glance, can hardly be considered a good vehicle for dialogue and symbiotic academic coexistence.

Hence, Lartey's use of 'postcolonialising' gave rise to the main research question of this article, namely how useful the notion of decolonisation is for inter-contextual dialogue in search of a symbiotic relationship between the Western and African notions of practical theology in the South African context.

\section{Aim and objectives}

The aim of this article is to explore and engage Lartey's notion of postcolonialising God and his subsequent notion of an African practical theology. This is done to establish whether the notion of post- or de-colonialising/colonising ${ }^{1}$ is helpful to the search for a symbiotic relationship between different notions (Western and African) of practical theology and, if necessary, to formulate proposals that may be conducive to a productive dialogue between the Western and African notions of practical theology in light of the decolonisation project.

Three objectives are set in order to achieve this aim:

- To provide an overview of the decolonisation project of Emmanuel Lartey's Postcolonializing God: An African practical theology (2013).

- To engage in a critical discussion of Lartey's Postcolonializing God and subsequent views on a so-called African practical theology.

- To identify and articulate some proposals that may be conducive to a productive dialogue between Western and African notions of practical theology

The following section provides an overview of the decolonisation project of Emmanuel Lartey (2013).

\section{Postcolonialising God: An African practical theology}

The purpose of this section is to provide a summative overview of Lartey's book (2013) in order to create a frame of reference for the critical discussion that is to follow. ${ }^{2}$

\section{Postcolonialisation and the postcolonialising God}

Lartey introduces the main issue of postcolonialisation as a form of criticism that is 'life enhancing ... opposed to every

1.Lartey (2013) prefers the term postcolonializing instead of decolonising, which is the commonly used term in the South African context. As the general aim is the same namely to free the previously subjugated from colonial influence, it is applied here as a term with the same meaning.

2.Unless otherwise indicated, all references are to Postcolonializing God: An African 2.Unless otherwise indicated, all references are to Postcolonializing God: An African
practical theology (hereafter referred to as Postcolonializing God). In this section Lartey's spelling of 'postcolonialization' serves to indicate that the reference is to his notion of decolonisation. 
form of tyranny, domination and abuse, its social goals are non-coercive knowledge produced in the interests of human freedom' (Lartey 2013:x). ${ }^{3}$

In the process, space is created for 'constructive critique of received theologies' (p. 11) and a re-appraisal of the 'African religious heritage' (p. 25) that includes aspects such as 'mystical connectivity through communal ritual' (p. 28) and 'pragmatic spirituality' (p. 30). Thus, Postcolonializing God can be regarded as a dialogical response to practical theological thought imposed on Africa.

Within this framework Lartey suggests that the term postcolonializing should be reformulated in two ways: as an adjective and a verb. "As an adjective "postcolonializing" qualifies the divine, offering thoughts describing an aspect of the nature of God' (p. xiii). Hence, 'God is seen as one who ... acts to decolonize ...' (p. xiii)

As a verb:

'postcolonializing' articulates the acts of people who seek to establish communities of faith reflecting the decolonializing nature of the divine which subverts or overturns the conditions established through colonialism creating forms of spiritual engagement that more truly reflect categories of thought and life that emanate from an African, rather than a European way of being and thinking. (p. xiii, [author's paraphrasing])

According to Lartey (p. xvi-xviii), postcolonialising activities are:

- counter hegemonic;

- strategic (actions with transformative intent, action-forchange orientation);

- hybrid, diverse, variegated and plural (ambiguous, contradictory, wary of over-privileging any form over all others);

- interactional and intersubjective (engaging with practices they wish to transform);

- dynamic (always fluid);

- polyvocal (creating room for the 'subjugated voices with despised knowledge'); and

- creative (producing new forms of being, institutions and practices).

In working out this thesis, Lartey (p. 1) dedicates the first chapter of this book, entitled 'God postcolonializes' to a 'postcolonial reading' of the tower of Babel narrative (Gn 11:1-9) as well as several New Testament passages (Mt 8:513, Mt 15:21-28, Lk 17:11-19, Lk 10:29-37 and Ac 2:1-42).

From this postcolonial reading of the Babel narrative Lartey deduces that they would debase and obliterate any differences among them ... They would insist on their way alone as being the way for all to follow. This is the essence of colonization' (p. 3 [author's paraphrasing]). However, God postcolonialises this scenario by confusing the language.

3.All further references to Lartey $(2013)$ will be indicated only by page numbers.
Hence, Lartey (p. 3) states that there are 'at least three lessons' that can be derived from this narrative:

- Diversity is the result of redemptive action - God acts to ensure this;

- God prefers diversity to hegemony; and

- God acts within the global community to affirm human diversity.

From the mentioned New Testament passages Lartey (p. 7) argues along the same lines, stressing that Jesus affirmed the faith of the non-Jewish community in his encounters with members, for example the faith of the Roman centurion Matthew 8:10 - and was 'less concerned about having everyone believe in the same way'. In the case of the SyroPhoenician woman, Lartey (p. 7) suggests that this woman challenged Jesus for 'his narrow focus and interpretation of his mission'.

According to Lartey (p. 12), this opens the door for a 'constructive critique of received theologies' whereby it is pointed out that we are currently still informed by 'exclusivist' interpretations of Scriptures that seems to be contradictory to Jesus' interaction across faith boundaries.

Lartey (p. 10) concludes this argument with reference to the 'polyvocal birthday of the church' found in the Pentecost: 'Polyvocality, as expressive of humanity's cultural diversity, is God's chosen means at Pentecost ... The new creation is to be a postcolonial reality'.

\section{The Postcolonialising God at work in faith practice and liturgy}

For the purpose of this summative overview, the second and third chapters of Postcolonializing God are grouped together as it provides a historical overview of Africans' postcolonialising of faith practice and liturgy - specifically in the United States of America.

Lartey provides a historical overview of how black Christianity and black spirituality found expression in new surroundings, like the United States of America, and how this rich religious heritage impacted on black life and thought. This expression serves as a form of spontaneous postcolonialisation or postcolonialisation in action, unveiling the unique texture of black Christianity and spirituality (p. 25).

From this, Lartey provides seven 'seminal' characteristics of African religious heritage:

- sacredness of all life

- plurality within the spiritual and divine realm

- mystical connectivity through communal ritual

- desire for cosmic harmony

- creativity and adaptability

- affirmation of life

- pragmatic spirituality

Chapter 3 concerns 'postcolonializing liturgical practice: Rituals of remembrance, cleansing, healing and re-connection' 
(p. 38) and serves as an illustration of what is meant by an African practical theology.

Lartey (p. 38) does not provide his own definition of liturgy, but rather uses an interfaith public ritual performed in Elmina, Ghana in 2007 (to celebrate Ghana's 50th year of independence and the 200th year of the abolition of the slave trade) as an example of an 'indigenised' form of practical theology (liturgy) 'which has clear global import'.

Lartey (p. 41) notes that the ritual in question was not organised by the institutional church in Ghana, but by a secular state department, as the church in Ghana is 'yet to be truly and fully engaged in "postcolonializing God"'. According to Lartey (pp. 45-56), this event is a good illustration of what an African practical theology (liturgy) should embody, as it included true African elements like drumming, a symbolic return of the enslaved; choir music; cleansing rituals, like the slaughter of a sacrificial ram; offering of prayers, greetings and salutations; remembrance of the ancestors; sermons and celebrations.

Thus, the particular event Lartey (pp. 57-62) applies is not the result of an African practical theology, but reminiscent to him of what he perceives as an African practical theology, as this event resonated with the seven attributes of postcolonializing actions mentioned previously.

\section{Transcending colonial religion}

In the fourth chapter of Postcolonializing God, Lartey (p. 65) turns his attention to the issue of 'Transcending colonial religion: Brother Ishmael Tetteh and the Etherean Mission'.

Starting with Lartey's concluding remark, 'In Brother Tetteh and the Etherean Mission we have the hallmarks of a genuinely postcolonializing African spiritual movement' (p. 117), this chapter engages and illustrates Lartey's interpretation of the decolonisation of colonial religion by means of drawing heavily on the work of the mystic Brother Ishmael Tetteh.

Tetteh's brainchild, the Etherean Mission, was introduced in Ghana in 1975 and has three objectives:

- To bring spiritual enlightenment to mankind;

- To create a platform for religious oneness;

- To restore the mystical traditions of Africa (p. 69).

Tetteh's 25 books draws on the 'ancestors', 'Bible, Qur'an' and 'Bhagavad Ghita' (p. 69-71). Tetteh, quoted by Lartey (p. 71), states: 'These books would become tools of bondage when they are used as the ceiling to religious life and study' and 'the Bible is neither the earliest nor the final authority on God and the Truth of life'.

Some of these 'transcending' elements, aimed at bringing spiritual enlightenment to the world, include the following:
- A God that is characterised as 'all prevailing Power and Presence behind all that exists' and is not limited to a 'sect' can therefore be Christian, Hindu or Muslim (p. 73).

- 'Christ the Universal Love is pervasive throughout the cosmos' (p. 75) and 'has been manifest in other Masters such as Krishna, Buddha, Muhammad and others as well'.

- 'Tetteh's anthropology is in many ways theological, spiritual and mystical' drawing heavily on the Bhagavad Gita in the view that man is eternal, with his intellect as the greatest difference between himself and animals (p. 77).

- Through EMAT (Etherean Mission Application Technology) Etehereans can attain holistic well-being (p. 77).

- The devil is an illusion (p. 80).

- The desires of man 'are various forms of God's manifestations' and 'must be beneficial to the universe' (p. 83).

- The purpose of humanity is 'karma, reincarnation and liberation' (p. 83).

\section{Postcolonialising pastoral care}

Chapter 5 deals with postcolonialising pastoral care. Central to Lartey's notion of a postcolonialised pastoral care is the premise that it is 'a double-edged sword with cutting surfaces that are community-building and "culture transforming"' (p. 119). The key or 'handle' that enables the wielding of this sword is 'spirituality' (p. 119).

Once again Lartey suggests that a postcolonialised pastoral care transcends conventional (Western) notions of pastoral care, especially in terms of anthropology. In his view, the 'central organizing aspect of human personality' is 'a Godgiven essence that is received or uniquely chosen from the divine realm prior to entry onto the earth plane ...' (p. 119). This 'God-given essence ... serves as the core or key driving force of a human being's life purpose ... This component links one with the divine while also being the core of one's psychology' ( $p$. 119). Western anthropologies are thus mere psychological reductionisms that fail to address Africans spiritually.

A decolonised pastoral care favours spirituality - but then in the African sense that has 'divine as well as psychological, social and ecological dimensions to its complexity' (p. 120). Pastoral care in this sense becomes focused on 'helping persons fulfill the life purpose and plan they chose and agreed to in the divine realm prior to their birth and entry onto this human plane of existence' (p. 120).

A postcolonialising pastoral care is also about 'building healthy community' (p. 120) and 'transforming cultures' (p. 122). The building of healthy communities focuses on a pastoral care of the community rather than on the pastoral counselling of the individual.

Although the one does not exclude the other, individual pastoral care to the exclusion of the community 'follows the pattern of ineffectual colonialism' (p. 121) and therefore all individual therapy must be set within 'a community building 
paradigm' (p. 121). Communal pastoral care thus expands to issues such as public policy, political processes, the emancipation of minority groups and other social uplifting endeavours such as the building of schools and hospitals. 'The goal of pastoral care is always the creation of healthy communities in which all persons can live humane lives' ( $p$. 122). This requires the cultures of communities to be transformed when a culture of disrespect towards the rights of others exist.

\section{Postcolonialisation as imperative}

Lartey's concluding argument in the sixth chapter (p. 124) is that postcolonialisation is a 'theological imperative', where the creative must steer the process as the ideal that follows upon mimicry of the coloniser and improvisation with the means available to Africans.

Ideally, an African practical theology will 'cease ... from the constant looking over its shoulder to see what former colonizers say and think of what it does' (p. 129).

\section{A critical engagement and discussion of Postcolonializing God: An African practical theology}

The aim of this section is a critical engagement with Lartey's notion of postcolonializing God and the subsequent African practical theology. It is, however, important to qualify the meaning of critical engagement, within the parameters of this article, in order to remain true to its focus. The focus of this article is to aid a productive dialogue between the Western and African notions of practical theology in the quest for a symbiotic co-existence. In this sense, it would defy the purpose of the article to simply judge Lartey's contribution against typical Western notions, for example of practical theology, exegesis and hermeneutics, and dismissing it because it does not resonate well with these existing ideas.

The critical question within the framework of this article would thus be whether the notion of Postcolonializing God has the ability to take us forward in the development of a relevant practical theology for current contexts - and, in this sense, a critical engagement is sought.

In general terms, the summative reading of Lartey creates the impression that an African practical theology is freed from all Western bondage by means of (the) postcolonializing God and practical theological actions that transcend colonial religion, liturgy and pastoral care - resulting in an authentic African practical theology. In this sense, what the African practical theology portrayed here is mainly aimed at reviving the subjugated African heritage that transcends the known boundaries of Western (colonial) theology.

Applying the critical question of whether this takes the dialogue between Western and African notions of practical theology forward, the answer can be 'yes' and 'no'. In terms of taking the dialogue forward, Lartey's exposition of an
African practical theology is helpful by elucidating what is meant by it. One of the main tenets of postcolonial criticism is that Westerners cannot decide on matters of an African nature, as Western knowledge about Africa is mostly not African at all (cf. Mbembe 2001:8). In this regard, Lartey's contribution is representative of an authentic African practical theology and not the fruit of Western thought. It takes the understanding of Western dialogue partners forward in terms of valid explanation and authentic representation.

On the other hand, the notion of decolonisation, as expressed in Postcolonializing God, is also not taking the dialogue between Western and African notions of practical theology forward. Once again, in general terms, the African practical theology, portrayed in Postcolonializing God, is a practical theology that leaves behind rather than accommodates. It transcends the typical Western notions of practical theology to places that are unreachable and inaccessible to the uninitiated and the non-African. Especially in terms of epistemology, it traverses uncharted territory. A point in case is drinking from the wells of ancestry, mysticism and syncretism in order to fuel pastoral care and liturgy. In so doing, it forces Western dialogue partners out of hearing range from their African counterparts to make the notion of decolonisation, as the vehicle to take constructive intercontextual dialogue forward, suspect.

More specifically however, a critical assessment of whether decolonisation is taking inter-contextual dialogue forward needs to take at least the following concerns into consideration.

\section{The need for an inclusive practical theology for multi-cultural and transitional realities}

Postcolonializing God in tandem with the current decolonisation movement in local academia is an urgent reminder that many voices from different cultures, ethnicities and genders were left unheard and subjugated over time. In this sense, decolonisation became a quest for reclaiming and reaffirmation of what is unique and dear in terms of identity, culture and knowledge. It should therefore come as no surprise that decolonisation drives are often accompanied by a new zeal for an own identity (cf. Kaunda 2015:78) that opens the door for new forms of isolation and sentiments of nationalism, because at its heart, decolonisation is 'against' the coloniser and colonisation. In essence, decolonisation creates the risk of losing sight of current realities and creating a romantic yearning for what 'could have been' instead of focusing on 'what we in fact became'.

Apart from current international trends of migration and globalisation, and the effects they have on the identities of individuals and collectives, the local context was also exposed to radical changes over the last few decades. After 1994, South Africans woke up to a context that is both multicultural and highly transitional in nature. Unfortunately, it cannot be denied that neither curricula nor ecclesial faith praxis has satisfactorily caught up with the transitional 
challenges that have become characteristic of the current local context (cf. Brunsdon \& Knoetze 2014; Meylahn 2015). This very reality poses the question whether decolonisation is the best option for the development of an appropriate practical theology for the current dispensation, as it certainly carries within it the potential to isolate rather than include the 'other'. This, while one of the main challenges for the present scenario is the development of an inclusive practical theology that bears as much as possible sensitivity towards all cultures, different identities, beliefs and values.

\section{The feasibility of 'perceived' contexts}

Decolonisation inevitably presupposes a context. A case in point here is the so-called African context for which Lartey, by means of postcolonial criticism, has produced an African practical theology.

The very notion of (the African) context portrayed here is problematic for a number of reasons. Among others, it resembles a very fluid concept in that it refers to any number of aspects, for example locality, nationality, culture, values and beliefs. It is thus challenged by questions starting with 'where', 'who' and 'why'. Applied to the so-called African context, questions such as Where is Africa?; Who is the African?; and Why are certain people deemed Africans and others not?, illustrates some of the challenges related to the notion of (the African) context. It is also challenged by recent self-conceptions of Africans such as Afropolitanism and Afropean (Ede 2016:88). This means that context can at best be 'perceived'. In other words, context can only be a representation of our own perception of a certain context that renders resultant contextual descriptions preliminary and fluid in itself.

The notion of the African context is subsequently insufficient and not inclusive enough. The African practical theology depicted in Postcolonializing God, for example, includes but a small portion of Africans, supposedly Afro-Americans who will willingly be associated with the liturgy and pastoral care described previously. Working with a perceived African context thus runs the risk of becoming limited to the point of being not useful. The very diversity of the African context (cf. Mbiti 1970) thus calls for contextual analysis and exegesis to become meaningful and specific.

\section{Culture, decolonisation and an African practical theology}

For non-African dialogue partners, the African practical theology depicted here resembles a very close relationship with African culture itself, challenging clear distinctions between religious and cultural aspects. Although culture is narrowly associated with African religions (Louw 2008:153; Du Plessis 2016:1), little or no distinction is possible in Lartey's African practical theology and makes it difficult to determine the true theological nature of the proposed practical theology. Cultural elements in faith are easier to distinguish within Christian theology, because culture is usually understood as being in service of faith as it is transformed by Christ (Niebuhr 1952:210). Still, what may be deemed by Western theologians as culture, may not, due to the interconnectedness between faith and culture among Africans, resemble any challenge to an African understanding of faith. The point in case here is Lartey's exposition of the seven 'seminal' characteristics of African religious heritage that include aspects such as plurality within the spiritual and divine realm, mystical connectivity through communal ritual and what Lartey (pp. 27-31) denotes as pragmatic spirituality. A closer inspection of these aspects reveal that 'communotheism', 'rituals', 'trance' and 'efficacious interactions with the unseen realm' form part of an African practical theology 'through courageous postcolonializing agency' (cf. p. 31). This opens the door for a practical theology they may well be a cultural reductionism rather than theology.

In an inter-contextual engagement these aspects, foreign to the Christian tradition, beg further discussion and clarity.

\section{Plotting the Christian narrative in an African practical theology}

The most pressing aspect in a critical discussion of the African practical theology emanating from Postcolonializing God pertains to the non-centrality of the Christian narrative in this approach to practical theology. Theology and the most basic understanding thereof is bound to the study of the triune God as revealed in Scripture - a principle that also resonates in most general conceptions of practical theology (Heyns \& Pieterse 1990:7; Osmer 2008:4; Swinton \& Mowat 2006:7). It is therefore of concern that the Christian narrative itself seems, for the most part, absent in the depicted African practical theology. In an inter-contextual dialogue, this necessitates the following question: What is theological about an African practical theology based on postcolonial criticism?

It is true that the work of Western missionaries is held in dim regard by postcolonial critics (Kang 2016:2), mainly as they stand accused of depriving the colonised of their own ways of believing (Lartey 2013:xii). Decolonisation, in this regard, will understandably be serious to reinstate all subjugated ways of believing and practicing of faith within a postcolonial theology. However, in an inter-contextual dialogue where practical theology is the focus, a clear distinction between historical forms of colonial religion and current expressions of the Christian faith needs to be sustained. The work of Western missionaries during the period of colonisation and the essence of the Christian narrative must not be confused nor treated as if it is the same. It would translate to an uncritical equation of the two. The Christian narrative can therefore be expected to stand central in an African practical theology, even if it emanated from postcolonial criticism - if it indeed claims to be theology. In light of this argument, the seamless movement between the Christian Gospel and other religious narratives, as described in Lartey's understanding of transcended colonial religion (chapter 4 of Postcolonializing God), is indeed of concern and should be a high priority in inter-contextual dialogue. 


\section{Preliminary synthesis}

By means of a preliminary synthesis and in order to propose an answer to the main research question of this article, namely how useful the notion of decolonisation is for intercontextual dialogue in search of a symbiotic relationship between the Western and African notions of practical theology in the South African context, the conclusion is that it is of restricted use. In light of the afore-going depiction and critical discussion, tangible concerns were raised about whether decolonisation is the most suitable vehicle for intercontextual dialogue.

Kwok Pui-lan (2015:116), however, reminds us that the value of postcolonial theory must not be denied [author's italics] as it offers 'embodied and theoretical insights for the discussion of changing identities ...'

Thus, in an attempt to move into better hearing distance, the final section of this article is devoted to remarks that may be helpful in terms of productive dialogue.

\section{Remarks on facilitating productive dialogue}

In an attempt to remark on taking the inter-contextual dialogue forward, I would like to latch onto some of the insights of Esther Acolatse (2014) ${ }^{4}$ and the notion of a pastoral hermeneutic of primal speech. My primary interest in this notion stems from the potential it has in negotiating the chasm that often exists between the Gospel and different contexts in practical theological thinking or to put it simply, its potential to help ensure that practical theology remains theological and is not overwhelmed by culture, interdisciplinarity or the social and political agenda when engaging the context in which it has to function.

Acolatse's notion of a pastoral hermeneutic of primal speech (2014:210) is built on the interdisciplinary method of pastoral care of Deborah van Deusen Hunsinger (1995) that relied on the Christological insights of Barth and his exposition of the Chalcedonian pattern of theology. Central to the so-called Chalcedonian pattern of theology is the relation between revelation and human history that found an analogy in the incarnation of Christ, being divine and human at the same time and where the divine preceded the human -in particular, the 'indestructible order' of the divine-human relation 'which again for Barth is giving priority to revelation over human history' (Acolatse 2014:10).

In Hunsinger's pastoral theology this gave rise to the 'bilingual' approach (Acolatse 2014:211) which means that pastoral theologians could engage other disciplines in their approach very much like a bilingual speaker who is able to switch between two languages without confusing the two.

4. Esther Acolatse hails from Ghana and is currently assistant professor at Duke Divinity School in Durham, North Carolina (USA). Much of her work focuses on the
intersection between 'psychology and Christian thought, particularly with respect intersection between 'psychology and Christian thought, particularly
to global expressions of Christianity' (see Duke Divinity School n.d.).
Hunsinger's bilingual approach is then used by Acolatse (2014) in the development of a pastoral hermeneutic of primal speech that takes the notion of the bilingual approach further in the sense that it accentuates faith-language as the primary or primal speech of the pastoral (practical) theologian:

I go so far as to say that for the Christian pastoral counsellor, this primal language should unequivocally be theological in nature, having Trinitarian breadth and Christological depth.

I advocate here an approach ... [where]...the text is primary and the context ... secondary. (p. 213)

Acolatse (2014:214) also links this train of thought to the work of the religion and missiology historian Lamin Sanneh and his notion of the translatability of the Gospel message. Sanneh (1989) articulates the phenomenon that the Gospel message of Pentecost was translated across cultures without losing its Christian nature. Acolatse refers to this as the 'expansive nature of theology ... that allows for hospitable encounters with other cultural reframing ... encounters' (Acolatse 2014) and can best be summarised in the following quotation:

Theology's expansive nature and its inherent ability to accommodate/incorporate the other disciplines without any real loss to its essence, in this sense, mimics that of the Triune God revealed in the incarnation, a God who condescends to be human without any real loss to divine attributes. (p. 215)

I deem these ideas helpful for the practical theological intercontextual dialogue as it creates space for what Acolatse (2014:206) also calls the perichoretic nature of cross-cultural and, in this case, inter-contextual, dialogue. Referring to the interrelatedness-through-distinction in trinitarian thought, it places conversation partners on the same level, allowing us to frequent the other's dwelling place as if it is our own. Yet, we are doing so from the stance of our primal voices that is expressive of the Christian faith - a faith that respects the divinely authored order through which it is recognised that God permeates culture and that the hallmark of all forms of theology is its trinitarian breadth and Christological depth. This will have implications for epistemology, the authority we attribute to cultural beliefs, the influence of ideology, and so forth - making theology itself the middle ground to which our dialogue aspires.

Conversation partners seeking a practical theology for any context will thus remain within hearing distance when approaching dialogue in their primal voices that can lead to a truly symbiotic relationship aimed at the local context.

\section{Synthesis}

This article was conducted within the framework of the intercontextual dialogue between the Western and African notions of practical theology. It set out to probe the usefulness of the notion of decolonisation in the design of practical theology. The application of this notion in Emmanuel Lartey's Postcolonializing God - An African practical theology (2013) was investigated as Lartey related the notion of postcolonialising to the design of an authentic African practical theology. An 
overview of Lartey's work was provided with the following question as subtext: Does the resultant African practical theology remain within 'hearing distance' of Western notions of practical theology? The criteria for answering this question were aligned with the purpose of the article, namely whether a practical theology, resulting from postcolonial criticism, can stimulate a symbiotic inter-contextual dialogue rather than dismissing a contextual approach that does not seem to conform to traditional Western approaches. It was found that decolonisation is of restricted use, as the resulting African practical theology was only partly within hearing range of a Western understanding. While it provided insight into an authentic African practical theology, a critical discussion raised concerns regarding inclusivity, the perceived context with which it worked, the interrelatedness between culture and faith as well as the very theological nature of this particular strand of African practical theology in light of Christology.

However, without denying the value of a practical theology based on postcolonial criticism, the concluding section of the article suggested that inter-contextual dialogue between the Western and African notions of practical theology can move forward on the basis of seeking the theological middle ground. In this regard the notion of Esther Acolatse's pastoral hermeneutic of primal speech was introduced that provides valuable parameters for inter-contextual dialogue. While it provides space for intercultural dialogue, it operates from the stance of a perichoretic relationship between theology and culture, meaning that faith in the triune God permeates culture and thereby going before culture and context. The resulting theologies therefore retain their trinitarian character. Such an approach carries promise to keep dialogue partners from different contexts within hearing distance from one another, creating space for symbiotic co-existence.

\section{Acknowledgements Competing interests}

The author declares that he has no financial or personal relationships which may have inappropriately influenced him in writing this article.

\section{References}

Acolatse, E.E., 2014, 'What is theological about practical theology? Toward a pastora hermeneutic of primal speech', Practical Theology 7(3), 205-220. https://doi.org/ 10.1179/1756073X14Z.00000000041

Berinyuu, A.A., 1988, Pastoral care to the sick in Africa: An approach to transcultural pastoral theology, Peter Lang Verlag, Frankfurt am Main.

Brunsdon, A.R. \& Knoetze, J.J., 2014, 'Batho Pele (People first): Some ethical and contextual reflections on theological training in an African context', in M.A. Mokoena \& I. Oosthuizen (eds.), Nuances of teaching learning and research, pp. 261-280, Andcorck Publishers, Potchefstroom. (Research and publication book series, 3)

Dames, G.E., 2014, A contextual transformative practical theology in South Africa, AcadSA Publishing, Parow.

Duke Divinity School, n.d., 'Ester Acolatse', viewed 31 July 2017, from https://tmc. divinity.duke.edu/our-people/esther-acolatse/

Du Plessis, A., 2016, 'A practical-theological reflection on the usage of symbols and metaphors in intercultural pastoral care in South Africa', HTS Teologiese Studies/ Theological Studies 72(2), a3517. https://doi.org/10.4102/hts.v72i2.3517

Ede, A., 2016, 'The politics of Afropolitanism', Journal of African Cultural Studies 28(1), 88-100. https://doi.org/10.1080/13696815.2015.1132622

Heleta, S., 2016, 'Decolonisation of higher education: Dismantling epistemic violence and Eurocentrism in South Africa', Transformation in Higher Education 1(1), a9. https://doi.org/10.4102/the.v1i1.9

Heyns, L.M. \& Pieterse, H.J.C., 1990, A primer in practical theology, Gnosis, Pretoria.

Kang, S.J., 2016, 'Postcolonial Reflection on the Christian Mission: The Case of North Korean Refugees in China and South Korea', Social Sciences 5(67), a11. https://doi. org $/ 10.3390 /$ socsci5040067

Kaunda, C.J., 2015, 'The denial of African agency: A decolonial theological turn', Black Theology 13(1), 73-92, April.

Lartey, E.Y., 2013, Postcolonializing God: An African practical theology, SCM Press, London.

Louw, D.J., 2008, Cura Vitae: Illness and healing of life, Lux Verbi BM, Wellington.

Masango, M., 2013, 'Pastoral theology in African contexts', in I.A. Phiri \& D. Werner (eds.), Handbook of theological education in Africa, pp. 744-754, Cluster Publications, Dorpspruit.

Mbiti, J.S., 1970, Concepts of God in Africa, Praeger Publishers, New York.

Mbembe, A., 2001, On the postcolony, University of California Press, Berkeley, California.

Meylahn, J.A., 2015, 'Doing theology in contexts of complex and shifting identities: A South African story', in P. Couture, R. Mager, P. McCarroll \& N. Wigg-Stevenson (eds.), Complex identities in a shifting world: Practical theological perspectives, pp. 101-111, LIT Verlag, Zürich. (International Practical Theology, 17).

Molefe, T.O., 2016, 'Oppression must fall: South Africa's revolution in theory', World Policy Journal 33(1), 30-37.

Niebuhr, H.R., 1952, Christ and culture, HarperCollins Publishers, New York.

Osmer, R.A., 2008, Practical theology: An introduction, Eerdmans, Grand Rapids.

Pui-lan, K., 2015, 'Changing identities and narrativities: Postcolonial theologies', in P. Couture, R. Mager, P. McCarroll \& N. Wigg-Stevenson (eds.), Complex identities in a shifting world: Practical theological perspectives, pp. 115-126, LIT Verlag, Zürich. (International Practical Theology, 17).

Sanneh, L., 1989, Translating the message: The missionary impact on culture, Orbis, New York.

Swinton, J. \& Mowat, H., 2006, Practical theology and qualitative research, SCM Press, London.

Van Deusen Hunsinger, D., 1995, Theology and pastoral counseling: A new interdisciplinary approach, Eerdmans Publishing, Grand Rapids. 